\title{
sciendo
}

\section{PROPOSAL OF AN OPERATIONAL MODEL TO MEASURE FEELINGS AND EMOTIONS IN URBAN SPACE}

\author{
ELHAM DARBAN REZAEE ${ }^{1, *}$, FATEMEH KALANTARI ${ }^{2}$ \\ ${ }^{I}$ Department of Urbanity, Faculty of Art and Architecture, Islamic Azad University, \\ Mashhad, Iran, E-mail: Elham.darbanrezaee@gmail.com \\ ${ }^{2}$ Department of Landscape Architecture, Faculty of Design and Architecture, University \\ Putra Malaysia, Serdang, Malaysia, E-mail: Fatimah.kalantari@gmail.com \\ *Corresponding author e-mail: Elham.darbanrezaee@gmail.com
}

Received: $2^{\text {nd }}$ May 2019, Accepted: $17^{\text {th }}$ August 2019

\begin{abstract}
People of different cultural backgrounds show different emotional reactions to different urban areas. Finding out how a constructed environment and emotional aspects are related and influence human behavior can be of a great significance in urban planning. Such studies are rooted in environmental psychology and socials sciences; there is a dearth of proper methods and techniques of evaluation with this regard. Moreover, so far there has been no academic study even a review of the relevant practical methods. Thus, there is a need for finding a valid objective evaluation procedure for emotional responses people make to urban space aiming to improve the design of urban areas and urban plan policymaking. In the present research, initially, a review of the research methodologies in environmental psychology, affect and emotions was done. Then, a qualitative content analysis of 30 of the latest projects and research was done in terms of the methodology and tools. Then, the final model was proposed in five stages based on the methods and tools of operationalizing the measurement of feelings and emotions in urban areas. The proposed model combined different research types and different methods applied in different disciplines and thus contribute greatly to solving urban problems.
\end{abstract}

Keywords: Feeling/Emotion, Methods and Measurement Tools, Urban Space, Emotional Response

\section{INTRODUCTION}

A body of related literature in environmental psychology shows that environmental properties and conditions affect preferences, priorities, perceived satisfaction, social interactions, and perceived mobility. The physical environment of a city plays a key role in determining citizens' behaviors, emotions and beliefs (Klettner et al., 2011). Just as individuals are categorized in different personality types, cities can also vary in type. Those of a stronger characteristic would influence citizens strongly. Different correlations can be found between a city and citizens' emotions. Such emotions as (un) happiness, (in) activity, (un)friendliness, peace, competition, and aggressiveness, characteristic of an environment and preferences, its choice and decision-making for any behavior in the target environment are all significantly influenced by one's affective responses to the environment. In fact, 
stimulus and environment are both perceived not only in terms of physical properties but also in terms of one's affective response to the environment. In other words, feelings help to highlight the potential consequences of a decision and thus help to one's sense-making and decision-making. When one receives a negative response from the environment, one begins to feel unhappy. Therefore, presence, social interactions, and type of activity in urban spaces are considered a key part of the external environment and urban life is strongly influenced by positive and negative feelings conveyed from the environment to individuals (Handgraaf et al., 2017; McAndrew, 1993). A key aspect of urban life which has been scarcely explored but is truly influential is how city life affects citizens' psychology. Cities influence emotions in multiple ways. There is a mutual effect between cities and citizens. Human life is associated with many experiences, perceptions, and emotions that would evoke certain emotions, progress, and dynamicity in life. Cities incorporate emotive, affective, logical, human and moral experiences (Nochian et al., 2015).

Today, modern life is marked with the latest technologies and has facilitated human life more than ever before. Many obstacles to a facile life are now removed. Yet, this kind of life is associated with new challenges that were not easily predictable such as stress, depression, and dissatisfaction. According to the World Health Organization (WHO), mental health is defined as one's capability of living happily and actively without certain challenges. Two points are to be considered in this definition, the first being that happiness is a considerably positive effect and the second being the fact that mental health has to do with interactions between individuals and their surroundings. In other words, according to WHO, one's mental health is kept when one is capable of living under physically, psychologically and emotionally healthy circumstances. Moreover, environmental psychology shows how spatial properties affect human feelings and behaviors and help to change behavior and adapt to space (Gifford, 2016), due to the human beings experience and express different emotions in urban spaces (Henshaw \& Mould, 2013). As an instance, some people would avoid certain places due to the stress or anxiety probably associated and on the contrary, get attracted to places, as they feel pleased. That is to say that stimulus and surrounding environment not only influence the physical properties but are also perceived through one's affective response. Therefore, citizens as the core component of an urban space play a key role through feelings in the process of urban investigations (Kalantari et al., 2015).

Moreover, experiencing desirable environments influenced by the qualities and properties of urban space would add to personal efficiency and concentration. On the other hand, experiencing undesirable environments can detach people more than before from places (Nochian et al., 2016). Consequently, researchers in the urban domain should be able to collect these environmental wants, orientations, and feelings through research methods and tools to investigate this knowledge in the realm of environmental psychology (Kalantari et al., 2018). Environmental psychology is deeply rooted in psychology, behavioral sciences, humanities, geography, and architecture (Handgraaf et al., 2017; McAndrew, 1993) and its core procedures and issues occur in these fields and daily physical conditions. Furthermore, environmental psychology focused on how one's behavior and feelings are influenced by the physical environment (Berleant, 2018; McAndrew, 1993). However, only environmental psychology systematically investigates the conditions on which such procedures occur (Mazumdar et al., 2018).

In environmental psychology, the techniques used for data collection and analysis seek to measure public environmental attitude, behavior, and recognition scientifically (Rezazadeh, 1999). Moreover, as this environmental psychology owes much to social psychology especially behavioral psychology, humanities, geography, and architecture, the relevant research methodologies are closely concerned with the target issues discussed in these 
Rezaee E. D., Kalantari F.: Proposal of an Operational Model to Measure Feelings and Emotions in Urban Space

domains. Thus, a key issue in the world of environmental psychology research is to find the right method and tool for research data collection and analysis (Berleant, 2018; Lindner, 2009; Mazumdar et al., 2018).

Edwards (Edwards, 1974) put forth the idea of 'the visual-conceptual relation gap' and proposed a model for cooperating designers and specializes in behavioral sciences. As he believed, social scientists are researchers and analysts using inductive research methods. They analyze a whole into its parts and seek to find the interrelationships. On the other hand, designers often deal with the whole or totality of matters. In other words, social sciences follow a scientific approach while the designer approach can be perceived as more artistic (Lundy \& Wade, 2011; Vinet \& Zhedanov, 2010). How matters are approached in the social sciences is through meticulous experimental research methods to test hypotheses. However, such hypotheses are irrelevant to the physical properties of the environment and consequently lack any design application. On the other hand, in the realm design, normative theories are used to make propositions about the high quality of physical environment known as the basics of design, while sometimes lacking any scientific root. In other words, primary hypotheses are accepted unmeasured as a theory and start to serve as the criterion of action (Rezazadeh, 1999).

In social sciences, as the main issue at hand is people rather than the environment, verbal descriptive methods are used more often. Accordingly, different techniques are developed and applied (Cook et al., 2012). Thus, using the recurrent methodologies in social sciences would require particular technical precisions especially in environmental interpretation. Furthermore, how the effect is measured is another aspect which comprises the core body of research technique and varies from one technique to another. A review of the related literature points to the dominance of psychological and design disciplines. There is a dearth of research into urban design and practical aspects. Yet, it can be assumed that the constituent elements of urban space, surrounding environment architecture, spatial configuration, space function, date and time layers, and constituent elements are so emotionally strong that can stimulate one's feeling of joy, happiness or fear. Furthermore, seminal related works of research and theories have touched the surface of the overall qualitative effect of environment (in the form of variables or macro-norms such as complexity, inadaptability, surprise, etc.) and not the actual instances in practice. Thus, they cannot be applied to urbanism and urban space design (Tress et al., 2018).

Considering the ambiguities in the existing research methods and data collections methods in environmental psychology and measurement methodology and data collection on feeling and emotion sources, here we first review the related research methods and tools in the valid body of research. Then, we attempt to propose an operational model to measure feelings and emotions in urban space.

\section{LITURTURE REVIEW}

In this section, first, we deal with the existing research methodology and data collection methods in environmental psychology and measurement methodology of feelings and emotions. Then, a sample of 30 projects has been analyzed.

\section{Research Methodology and Data Collection Methods in Environmental Psychology}

The foremost issue in using methods in social sciences and psychology in urban design is the lack of techniques to illustrate the physical body of the space (Berleant, 2018). However, the research methods in the social sciences and psychology were welcomed in measuring 
environmental quality and as a result, a greater variety of techniques were gradually developed to look into the environmental quality and its correlates. Simultaneously, older techniques were corrected according to the topic of research (Nardi, 2018). An instance can be the use of images as photos, slides, films and so on as an alternative for verbal suggestions of space on the one hand and presence at the space on the other. Therefore, particularly the interview and questionnaire methods were used to better fit the environmental studies. However, besides the general research methods in psychology, environmental psychologists used certain methods too which responded well to their different questions as will be discussed in the proceeding. The related literature showed that these investigations were generally categorized as exploratory and hypothesis-testing. However, as research into environmental psychology issues is not as old as other disciplines, the complicated structure of processes indicative of human-environment interaction need to be explored further (Wertz, 2005). Gifford (Gifford, 2016) and before of that the McAndrew (McAndrew, 1993) introduced the main research methods in environmental psychology as experimental, quasi-experimental and correlational. Bell et al. (Bell et al., 2001) Introduced the main research methods in environmental psychology as experimental, correlational and descriptive and further emphasized that in environmental psychology projects, descriptive methods are applied more as they are more flexible. These methods are further described in Table 1 (Gifford, 2016; McAndrew, 1993).

Table 1: The main research methods in environmental psychology (source: (Gifford, 2016; McAndrew, 1993))

\begin{tabular}{|c|c|}
\hline $\begin{array}{c}\text { Main research methods in } \\
\text { environmental psychology }\end{array}$ & Method Description \\
\hline Experimental & $\begin{array}{c}\text { The researcher makes a practical change to the environment to create } \\
\text { the desired conditions to explore. In fact, s/he changes one or more } \\
\text { independent variables to test its effect on the dependent variable. }\end{array}$ \\
\hline Quasi-experimental & $\begin{array}{c}\text { This research enjoys part of the properties of an experiment but lacks } \\
\text { one or more conditions for a true experiment. Thus, in a specific period } \\
\text { of time, the experimental group behavior is tested before and after the } \\
\text { treatment. }\end{array}$ \\
\hline Correlational & $\begin{array}{c}\text { The researcher tests two or more variables in their natural state. In fact, } \\
\text { the variables and subjects are tested without any intervention to find } \\
\text { whether there is any systematic relationship between the variables. }\end{array}$ \\
\hline Descriptive & $\begin{array}{c}\text { The researcher makes no intervention in the environment and merely } \\
\text { describes the things, people, and reactions as they actually are. Analysis } \\
\text { of the observations would determine the results. }\end{array}$ \\
\hline
\end{tabular}

It is noteworthy that researchers often select one or a combination of these methods according to their topic of research and purpose of research. Moreover, these methods can be used both in the laboratory (recreated environment) and in the field study (real environment) (Gifford, 2016) each with certain advantages and disadvantages. What matters most to researchers is that the research is done in a natural state. Thus, it can be concluded that the relationship between the status of some research and the research methodology type used is not predetermined. Therefore, the researcher's decisions on the relative fitness of the experiment or field study is not a function of the research methodology used (McAndrew, 1993).

In environmental psychology, the required data can be collected in different methods and techniques. Besides questionnaires and interviews and the content analysis of archives 
Rezaee E. D., Kalantari F.: Proposal of an Operational Model to Measure Feelings and Emotions in Urban Space

sources, gaining information through observation is itself possible through many techniques (Gifford, 2016; McAndrew, 1993). It is noteworthy that a combination of these methods can be used in any single research depending on the topic at hand, the purpose of research and the use of deeper and more reliable findings. These methods based on the literature review, are summarized in Figure 1 which represents the research methods and data collection techniques in environmental psychology.

Fig. 1: Data collection methods and techniques in environmental psychology based on the literature review (source: Author's summarize)

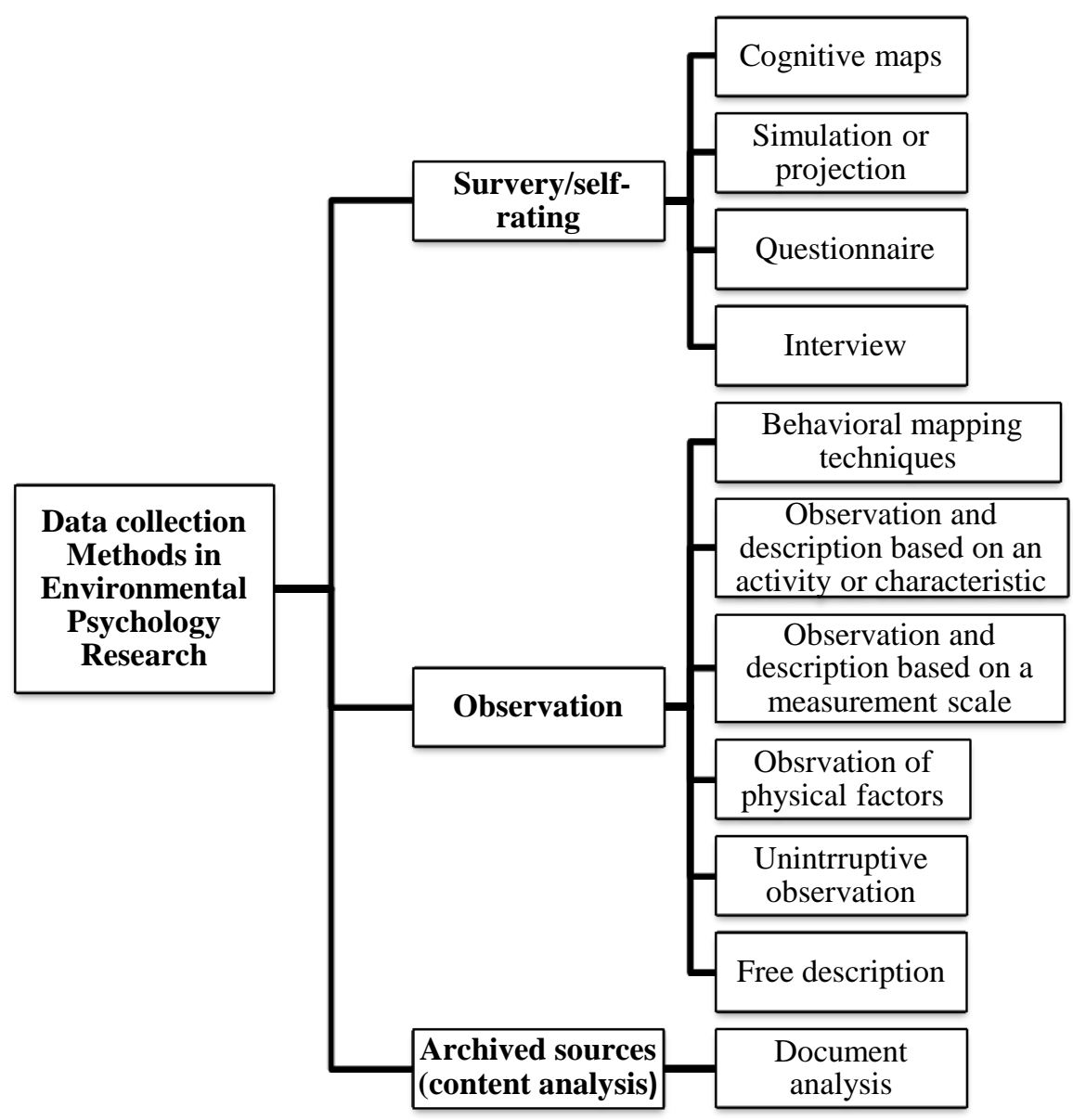

\section{Measurement Methodology and Data Collection of Feelings and Emotions}

Second In the past, there were fewer attempts at exploring feelings and the relevant concepts through measurement and quantification. Overall, feelings/emotions have been more addressed as exclusively qualitative and non-materialistic issues not capable of being measured. Why feelings/emotions have not been treated quantitatively is that they are unobservable and non-materialistic. Moreover, the complexity of feelings and the fluid nature of emotions add to these reasons. Not only are feelings expressed simultaneously and 
in combination, but are sometimes present and sometimes absent which makes them hard to measure (Holbrook \& Hirschman, 1982; Rezazadeh, 1999; Russell, 2003; Scherer, 2005).

Altogether though not much has been done to recognize feelings and emotions in general and environmental feeling and emotion in particular, the majority of sociologists discuss the cultural load of spaces and places. This is particularly true of architects and designers who are more obsessed with space and seek to form desirable spaces. There is a consensus that feelings and emotional changes, whether known as values or attitudes, affect behaviors and spatial desirability and satisfaction (Mancini et al., 2009; Ujang et al., 2018). However, due to the lacking knowledge of scientific methods, personal perception of the environment has replaced the recognition of public perception and the feelings and emotions expressed by users. In other words, phenomenological, illuminating and non-objective methods with an emphasis on elitism have replaced public recognition of the environment. Though it has been so for long, since the past few decades, regular systematic attempts have been made to approach the realm of feelings and emotions scientifically (Graumann, 2002). It is also noteworthy that though a mere focus on physical unconscious reactions such as the duration of staring, heart rate, galvanic skin response and the like unravels the relationship between a phenomenon and feelings, it fails to reveal the intervening perceptual process involved. On the other hand, a focus on behaviors neglects a series of perceptual processes involved. Using a certain space can be explained by different reasons. It might be due to emotion or peace. Thus, it does not necessarily point to peace or be the cause of emotions. It might even overshadow secondary factors such as social expectations and leave no chance for the emergence of behaviors according to one's perceptions and feelings. Architecture and urban design can attract, reinforce and establish short-lived, minor desires and thus provide permanent access to a wide range of feelings often experienced, on other occasions, only randomly (De Botton, 2008). As an instance, space can convey both peace and pleasure but to different degrees. Thus, you should go for a method that can more explicitly shed light on the correlation between the external environment and human perception and feeling.

Different investigations in the realm of social sciences and psychology have taken advantage of different research methods and techniques in accordance with their topic and purpose of research. These have been much more advanced than in the past due to new technologies. Besides, in these investigations, experimental, quasi-experimental, laboratory research, field research methods or a combination have been used (Gifford, 2016; McAndrew, 1993). These methods are summarized in Figure 2 based on the literature review. Figure 2 represents the data collection methods and techniques to measure feelings and emotions.

Today, advanced technology has created the chance of collecting interview or questionnaire data not only through old methods but also through smartphones. This way, the data are collected via mobile phones or social networks as latent large-scale data. Access to the applications, phone calls, messages, emails and history of internet search and location of smartphone users and analyzing them, certain emotional modes can be discovered. In addition, observation of facial expressions or voice of people via the required software and devices, feelings and emotions can be studied. Moreover, observing and recording physiological signals through perspiration devices, EEG, electrocardiograms, heart rate, blood pressure, skin temperature and the state of muscles can specify physiological changes in the body and track emotions (Gifford, 2016; Henshaw et al., 2012; Henshaw \& Mould, 2013; Jiao, 2015; Nardi, 2018; Nold et al., 2008; Podsakoff et al. 2003). However, most of these devices are incapable of showing the factors producing such signals of a certain emotion to find which there a need for mixed methods of data collection is. 
Rezaee E. D., Kalantari F.: Proposal of an Operational Model to Measure Feelings and Emotions in Urban Space

Fig. 2: Data collection methods and techniques to measure feeling and emotions based on the literature review (source: Author's summarize)

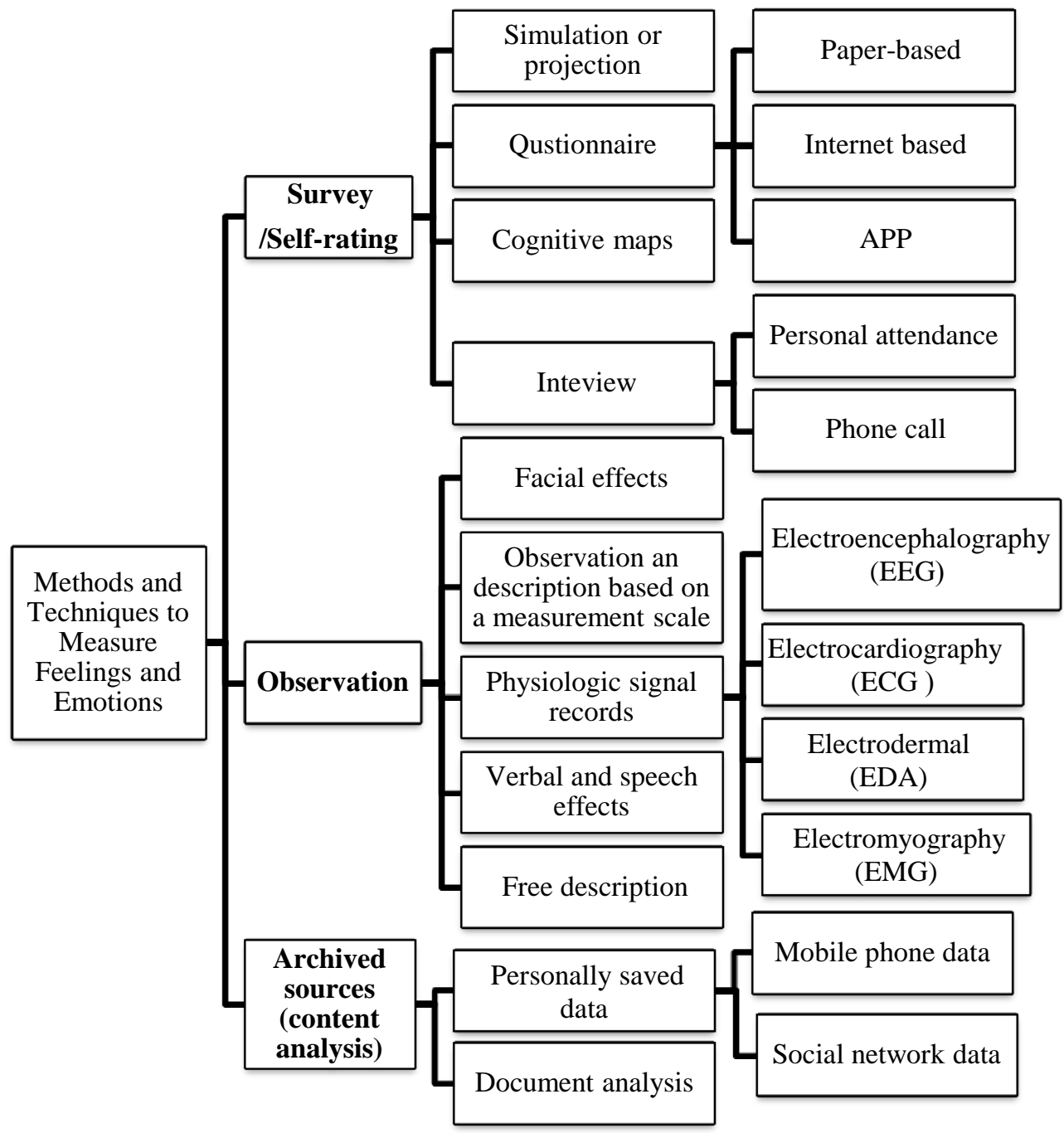

\section{Review of the Selected Projects}

To review and investigate the research methods and data collection procedures used in environmental psychology and urban studies on the emotion and feeling topic, 30 projects were selected as a sample. The content of these projects was analyzed in terms of procedures and results as well as data collection tools according to the items extracted from Figure 1 and more specifically Figure 2. Accordingly, these projects were categorized in terms of the main research methods in environmental psychology as summarized in Table 1. Table 2 shows the procedures in detail. 
Table 2: Description of the 30 projects selected in terms of the achievements, procedures and data collection tools

\begin{tabular}{|c|c|c|c|c|c|c|}
\hline & year & Project/ Research & Procedures & Research method & Location & Reference \\
\hline 1 & 1998 & $\begin{array}{l}\text { The Evaluative } \\
\text { Image of the City }\end{array}$ & $\begin{array}{l}\text { 1. Phone interview and questionnaire } \\
\text { (subjective perceptions) with the } \\
\text { environmental analysis technique } 2 \text {. } \\
\text { Analysis of the results and presenting } \\
\text { them on maps }\end{array}$ & $\begin{array}{l}\text { Correlational and } \\
\text { field experiment }\end{array}$ & $\begin{array}{l}\text { Knoxville and } \\
\text { Chattanooga, } \\
\text { USA }\end{array}$ & (Nasar 1990) \\
\hline 2 & 2001 & $\begin{array}{l}\text { Fear and } \\
\text { Misperception of } \\
\text { Los Angeles Urban } \\
\text { Space- A } \\
\text { Spatial-Statistical } \\
\text { Study of } \\
\text { Communication-Sha } \\
\text { ped Mental Maps }\end{array}$ & $\begin{array}{l}\text { 1. Use of cognitive maps } 2 \text {. GIS } \\
\text { modeling of cognitive maps } 3 \text {. } \\
\text { Spatial/statistical analysis } 4 \text {. } \\
\text { Presentation of the results on maps }\end{array}$ & Field research & $\begin{array}{l}\text { Los Angeles, } \\
\text { USA }\end{array}$ & $\begin{array}{l}\text { (Matei, } \\
\text { Ball-Rokeach, } \\
\text { and Qiu 2001) }\end{array}$ \\
\hline 3 & 2004 & $\begin{array}{l}\text { Bio Mapping / } \\
\text { Emotion Mapping }\end{array}$ & $\begin{array}{l}\text { 1. Galvanic skin response device } \\
\text { (GSR) and GPS 2. Extraction of } \\
\text { stressors 3. Mapping and determining } \\
\text { the rate of stress in urban spaces }\end{array}$ & $\begin{array}{l}\text { Field } \\
\text { experiment-descri } \\
\text { ptive }\end{array}$ & $\begin{array}{l}\text { London, } \\
\text { Greenwich, } \\
\text { Nottingham, } \\
\text { Portsmouth, } \\
\text { Huddersfield } \\
\text { Kensington, } \\
\text { England. } \\
\text { Rotterdam, } \\
\text { Nederland. } \\
\text { Siena, Italy. } \\
\text { Somnelina } \\
\text { Castle, Finland. }\end{array}$ & $\begin{array}{l}\text { (Nold 2009) } \\
\text { (Nold, Jensen, } \\
\text { and Harder } \\
\text { 2008) }\end{array}$ \\
\hline 4 & 2009 & $\begin{array}{l}\text { VEMap } \\
\text { (Virtual Emotion } \\
\text { Map) }\end{array}$ & $\begin{array}{l}\text { 1. GSR+ electrocardiograph } 2 \text {. } \\
\text { Analysis of previously extracted data } \\
\text { through the comparative description of } \\
\text { a computerized 3D space creation }\end{array}$ & $\begin{array}{l}\text { Field experiment- } \\
\text { descriptive }\end{array}$ & Ontario, Canada & (Zhu 2009) \\
\hline 5 & 2009 & Mapping people & $\begin{array}{l}\text { 1.A smart electrocardiography and } \\
\text { skin temperature measure bracelet + } \\
\text { GPS + short answer statements made } \\
\text { at pre-specified points of the } \\
\text { questionnaire (two individuals were } \\
\text { asked to move within the same limits } \\
\text { simultaneously) 2. analysis of the data } \\
\text { and presentation of 3D maps }\end{array}$ & $\begin{array}{l}\text { Field } \\
\text { experiment-field } \\
\text { research-correlatio } \\
\text { nal }\end{array}$ & $\begin{array}{l}\text { Berlin, } \\
\text { Germany }\end{array}$ & $\begin{array}{l}\text { (Zeile, Höffken, } \\
\text { and } \\
\text { Papastefanou } \\
\text { 2009) }\end{array}$ \\
\hline 6 & 2009 & WiMo & $\begin{array}{l}\text { 1. Use of ethnography and focus } \\
\text { groups of participants } 2 \text {. Social } \\
\text { network analysis+ GPS } 3 \text {. Analysis of } \\
\text { data and presenting maps }\end{array}$ & $\begin{array}{l}\text { Descriptive-correl } \\
\text { ational }\end{array}$ & $\begin{array}{l}\text { Berlin, } \\
\text { Germany }\end{array}$ & $\begin{array}{l}\text { (Mody, Willis, } \\
\text { and Kerstein } \\
\text { 2009) }\end{array}$ \\
\hline 7 & 2010 & $\begin{array}{l}\text { Fuehlmeter } \\
\text { (Feel-o-meter) }\end{array}$ & $\begin{array}{l}\text { 1. Grading feelings in space and time } \\
\text { through the Emomap application } 2 \text {. } \\
\text { Data storage on an open-source online } \\
\text { database } 3 \text {. Modeling and constructing } \\
\text { a mental-affective layer of space } 4 \text {. } \\
\text { mapping in software }\end{array}$ & $\begin{array}{l}\text { Descriptive-correl } \\
\text { ational }\end{array}$ & $\begin{array}{l}\text { Lindau, } \\
\text { Germany }\end{array}$ & $\begin{array}{l}\text { (Iaconesi and } \\
\text { Persico 2013) } \\
\text { (Iaconesi and } \\
\text { Persico 2014) }\end{array}$ \\
\hline 8 & 2011 & EmoMap & $\begin{array}{l}\text { 1. Capturing people's face with a } \\
\text { camera 2. Software-based data } \\
\text { analysis 3. mechanical data analysis } \\
\text { and modification }\end{array}$ & Descriptive & Vienna, Austria & $\begin{array}{l}\text { (Klettner, } \\
\text { Huang, and } \\
\text { Schmidt 2011) }\end{array}$ \\
\hline 9 & 2011 & $\begin{array}{l}\text { Emotional } \\
\text { Barrier-GIS-A New } \\
\text { Approach to Integrate } \\
\text { Barrier-Free Planning } \\
\text { in Urban Planning } \\
\text { Processes }\end{array}$ & $\begin{array}{l}\text { 1. Selecting two groups, a blind and a } \\
\text { disabled to walk } 2 \text {. Data collection } \\
\text { through the smart bracelet and GPS } 3 \text {. } \\
\text { Data analysis through a multi-layered } \\
\text { fuzzy model } 4 \text {. pointing put the spatial } \\
\text { stressor obstacles }\end{array}$ & $\begin{array}{l}\text { Field } \\
\text { experiment-correl } \\
\text { ational }\end{array}$ & $\begin{array}{l}\text { Kaiserslautern, } \\
\text { Germany }\end{array}$ & $\begin{array}{l}\text { (Bergner et al. } \\
\text { 2011) }\end{array}$ \\
\hline
\end{tabular}


Rezaee E. D., Kalantari F.: Proposal of an Operational Model to Measure Feelings and Emotions in Urban Space

\begin{tabular}{|c|c|c|c|c|c|c|}
\hline 10 & 2012 & Mappiness & $\begin{array}{l}\text { 1.A daily reminder of the program and } \\
\text { asking about feeling toward space and } \\
\text { recording one's geographical location } \\
\text { 2. The recorded sound of the } \\
\text { environment } 3 \text {. Data analysis and } \\
\text { presentation on maps }\end{array}$ & $\begin{array}{l}\text { Field } \\
\text { research-correlatio } \\
\text { nal-descriptive }\end{array}$ & England & $\begin{array}{l}\text { (Iaconesi and } \\
\text { Persico 2014) } \\
\text { (Iaconesi and } \\
\text { Persico 2013) }\end{array}$ \\
\hline 11 & 2012 & Sensing the city & $\begin{array}{l}\text { 1. Completion of the standardized } \\
\text { noise questionnaire (ICBEN) 2. Smart } \\
\text { bracelet and arm strap to measure skin } \\
\text { wetness and temperature + neck-worn } \\
\text { cameras to capture and recognize } \\
\text { visual or audiovisual effects } 3 \text {. Use of } \\
\text { Immersion control software to locate } \\
\text { people geographically } 4 \text {. Data analysis } \\
\text { through SPSS, GIS EXCEL, Premier } \\
\text { 5. Creation of an emotional layer }\end{array}$ & $\begin{array}{l}\text { Field } \\
\text { experiment-correl } \\
\text { ational }\end{array}$ & $\begin{array}{l}\text { Kaiserslautern, } \\
\text { Germany }\end{array}$ & $\begin{array}{l}\text { (Bergner et al. } \\
\text { 2012) }\end{array}$ \\
\hline 12 & 2012 & Testing, Testing & $\begin{array}{l}\text { 1. Smart bracelet to measure skin } \\
\text { wetness and temperature } 2 \text {. Use of } \\
\text { mobile phone application to set the } \\
\text { geographical location and report the } \\
\text { current mood in a certain place } 3 \text {. Short } \\
\text { answer report of the stimulation rate } 4 \text {. } \\
\text { Data analysis and setting urban spaces } \\
\text { and the positive affective factors }\end{array}$ & $\begin{array}{l}\text { Field } \\
\text { experiment-correl } \\
\text { ational }\end{array}$ & $\begin{array}{l}\text { New York, } \\
\text { USA. } \\
\text { Berlin, } \\
\text { Germany. } \\
\text { Bombay, India. }\end{array}$ & $\begin{array}{l}\text { (Iaconesi and } \\
\text { Persico 2013) } \\
\text { (Iaconesi and } \\
\text { Persico 2014) }\end{array}$ \\
\hline 13 & 2012 & $\begin{array}{l}\text { Emotional } \\
\text { Wayfinding }\end{array}$ & $\begin{array}{l}\text { 1. Use of two types of bicycles, } \\
\text { conventional and electrical along a } \\
\text { certain pathway but under different } \\
\text { environmental conditions (topography } \\
\text { of the land, cross-section, high/low } \\
\text { traffic pathway, main street, etc.) } 2 \text {. } \\
\text { Measurement of stress via a smart } \\
\text { bracelet to check the skin temperature } \\
\text { and wetness, record of voice and } \\
\text { images + GPS } 3 \text {. data analysis and } \\
\text { creation of a thermal layer to append to } \\
\text { Google map }\end{array}$ & $\begin{array}{l}\text { Field } \\
\text { experiment-Correl } \\
\text { ational }\end{array}$ & Vienna, Austria & (Gartner 2012) \\
\hline 14 & 2012 & $\begin{array}{l}\text { Modeling Affective } \\
\text { Responses to Space }\end{array}$ & $\begin{array}{l}\text { 1. Use of the SD software on a } \\
\text { smartphone } 2 \text {. Asking about people's } \\
\text { feeling about environmental factors } \\
\text { and recording their emotional clues } 2 \text {. } \\
\text { Creation of specific emotional layers } \\
\text { and points } 3 \text {. Data analysis and map } \\
\text { creation }\end{array}$ & $\begin{array}{l}\text { Field } \\
\text { research-correlatio } \\
\text { nal }\end{array}$ & Vienna, Austria & $\begin{array}{l}\text { (Klettner and } \\
\text { Gartner 2012) }\end{array}$ \\
\hline 15 & 2012 & $\begin{array}{l}\text { Emotion in Motion: } \\
\text { A Methodology for } \\
\text { investigating } \\
\text { Emotional Response } \\
\text { to the Streets and } \\
\text { Urban Spaces in } \\
\text { Hanley, } \\
\text { Stoke-on-Trent }\end{array}$ & $\begin{array}{l}\text { 1. Capturing spatial emotional } \\
\text { experiences and environmental factors } \\
\text { via a multi-stratified method or } \\
\text { repeated measures } 2 \text {. Use of } \\
\text { positive/negative expressive terms and } \\
\text { evaluation through a } \\
\text { mobile-phone-based online } \\
\text { questionnaire + GPS } 3 \text {. Recognition of } \\
\text { the relevant factors through a } \\
\text { hierarchical structure at two levels of a } \\
\text { spatial model }\end{array}$ & $\begin{array}{l}\text { Field } \\
\text { research-correlatio } \\
\text { nal, descriptive }\end{array}$ & $\begin{array}{l}\text { Manchester, } \\
\text { England }\end{array}$ & $\begin{array}{l}\text { (V Henshaw et } \\
\text { al. 2012) }\end{array}$ \\
\hline 16 & 2013 & Mapping Feeling & $\begin{array}{l}\text { 1. Electrocardiography }+ \text { the optical } \\
\text { lux unit }+ \text { intensity of voice in the } \\
\text { vicinity } 2 \text {. Questionnaire completion } \\
\text { in urban space } 3 \text {. analysis and map } \\
\text { production }\end{array}$ & $\begin{array}{l}\text { Field } \\
\text { experiment-field } \\
\text { research-correlatio } \\
\text { nal }\end{array}$ & Ramon, Israel & $\begin{array}{l}\text { (Weinreb and } \\
\text { Rofè 2013) }\end{array}$ \\
\hline
\end{tabular}


Journal of Landscape Ecology (2019), Vol: 12 / No. 3

\begin{tabular}{|c|c|c|c|c|c|c|}
\hline 17 & 2013 & Aleph of Emotion & $\begin{array}{l}\text { 1. A one-year ethnography } 2 . \\
\text { Extraction of emotions via a } \\
\text { questionnaire and graded description } \\
\text { of different urban areas in public } \\
\text { places at different scales at two } \\
\text { different times of the year and different } \\
\text { hours of day/night } 3 \text {. Production of } \\
\text { cognitive maps and environmental } \\
\text { preferences } 4 \text {. data analysis and } \\
\text { production of an effective map of each } \\
\text { place }\end{array}$ & $\begin{array}{l}\text { Field } \\
\text { research-correlatio } \\
\text { nal }\end{array}$ & $\begin{array}{l}\text { Singapore, } \\
\text { Singapore }\end{array}$ & $\begin{array}{l}\text { (Vigneshwara } \\
\text { 2014) }\end{array}$ \\
\hline 18 & 2014 & $\begin{array}{l}\text { Visualizing } \\
\text { Emotional } \\
\text { Landmarks in Cities. }\end{array}$ & $\begin{array}{l}\text { 1. Categorization of feelings expressed } \\
\text { about each place on Twitter } 2 \text {. } \\
\text { Analysis of spatial data via a } \\
\text { camera-like device equipped with a } \\
\text { compass + accelerometer + GPS } 3 \text {. } \\
\text { locating each place on the map plus an } \\
\text { appended effective table of that place }\end{array}$ & $\begin{array}{l}\text { correlational, } \\
\text { descriptive }\end{array}$ & Rome, Italy & $\begin{array}{l}\text { (Iaconesi and } \\
\text { Persico 2014) }\end{array}$ \\
\hline 19 & 2014 & Emotional Compass & \multirow{2}{*}{$\begin{array}{l}\text { 1. Data extraction, classification and } \\
\text { interpretation (emotional terms from } \\
29 \text { languages, likes and forwards) in } \\
\text { social networks following a } \\
\text { software-based conceptual analysis } \\
\text { method (LSA) 2. Production of 3D } \\
\text { emotional maps of different spots } \\
\text { recorded in social networks } 3 \text {. } \\
\text { Production of communicative maps to } \\
\text { find places of similar feelings } 4 \text {. } \\
\text { Development of an emotional compass } \\
\text { based on the urban emotional clues } \\
\text { through a mobile phone application }\end{array}$} & $\begin{array}{l}\text { correlational, } \\
\text { descriptive }\end{array}$ & $\begin{array}{l}\text { London, } \\
\text { England. } \\
\text { Rome and } \\
\text { Turin, Italy. } \\
\text { Berlin, } \\
\text { Germany. } \\
\text { Hong Kong. }\end{array}$ & $\begin{array}{l}\text { (Iaconesi and } \\
\text { Persico 2013) }\end{array}$ \\
\hline 20 & 2014 & $\begin{array}{l}\text { The Shortest Path to } \\
\text { Happiness: } \\
\text { Recommending } \\
\text { Beautiful, Quiet, and } \\
\text { Happy Routes in } \\
\text { City }\end{array}$ & & $\begin{array}{l}\text { correlational, } \\
\text { descriptive }\end{array}$ & $\begin{array}{l}\text { London, } \\
\text { England. } \\
\text { Boston, USA. }\end{array}$ & $\begin{array}{l}\text { (Quercia, } \\
\text { Schifanella, and } \\
\text { Aiello 2014) }\end{array}$ \\
\hline 21 & 2014 & EmoBeL & $\begin{array}{l}\text { 1. An online questionnaire (display of } \\
\text { several photos of selected areas and } \\
\text { evaluating } 3 \text { feelings on a website) } 2 \text {. } \\
\text { Expression of feelings at the presence } \\
\text { of people on spot } 3 \text {. Graph production } \\
\text { of the target location of selected } \\
\text { images on pathfinding maps }\end{array}$ & $\begin{array}{l}\text { Experimental } \\
\text { (recreated } \\
\text { environmental } \\
\text { positions)-field } \\
\text { research-descripti } \\
\text { ve }\end{array}$ & $\begin{array}{l}\text { Alexandria, } \\
\text { Egypt. }\end{array}$ & $\begin{array}{l}\text { (Raslan, } \\
\text { Al-hagla, and } \\
\text { Bakr 2014) }\end{array}$ \\
\hline 22 & 2015 & SensorMapRT & $\begin{array}{l}\text { 1.integrated use of two mobile-phone } \\
\text { applications: a. Emap (connected to } \\
\text { GPS) which enquires about how users } \\
\text { feel while moving in an environment }+ \\
\text { SMART bands, a biometric sensor b. } \\
\text { Emotion Sense application which } \\
\text { collects environmental data } 2 \text {. Data } \\
\text { analysis in EmoBeL } 3 \text {. Production of } \\
\text { an emotional map based on behavior in } \\
\text { any place }\end{array}$ & $\begin{array}{l}\text { Field } \\
\text { experiment-correl } \\
\text { ational }\end{array}$ & $\begin{array}{l}\text { Neustadt an der } \\
\text { Weinstrasse and } \\
\text { Pirmasens, } \\
\text { Germany. }\end{array}$ & $\begin{array}{l}\text { (Exner et al. } \\
\text { 2015) }\end{array}$ \\
\hline 23 & 2016 & Emo cycling & $\begin{array}{l}\text { 1. Mixed laboratory research and field } \\
\text { research } 2 \text {. Electrocardiography and } \\
\text { blood pressure at a natural state } 3 \text {. Use } \\
\text { of sensors to be worn (to check heart } \\
\text { rate and blood pressure) in two areas of } \\
\text { different features +GPS } 4 \text {. Data } \\
\text { analysis via Geo Visualizer, map and } \\
\text { image production }\end{array}$ & $\begin{array}{l}\text { Field } \\
\text { experiment-field } \\
\text { research- } \\
\text { correlational }\end{array}$ & $\begin{array}{l}\text { Remse, } \\
\text { Germany }\end{array}$ & $\begin{array}{l}\text { (Groß and Zeile } \\
\text { 2016) }\end{array}$ \\
\hline 24 & 2016 & $\begin{array}{l}\text { Geostatistical } \\
\text { Analysis for the } \\
\text { Study of } \\
\text { Relationships } \\
\text { between the }\end{array}$ & $\begin{array}{l}\text { 1. Using a field experiment, people are } \\
\text { asked to take photos along a certain } \\
\text { path ( } 2.2 \mathrm{~km} \text { in a various urban area) } \\
\text { and certain places, wait at least for } 5 \\
\text { seconds till their smart bracelet records }\end{array}$ & $\begin{array}{l}\text { Field experiment- } \\
\text { correlational }\end{array}$ & $\begin{array}{l}\text { Zurich, } \\
\text { Switzerland }\end{array}$ & $\begin{array}{l}\text { (Hijazi et al. } \\
\text { 2016) }\end{array}$ \\
\hline
\end{tabular}


Rezaee E. D., Kalantari F.: Proposal of an Operational Model to Measure Feelings and Emotions in Urban Space

\begin{tabular}{|c|c|c|c|c|c|c|}
\hline & & $\begin{array}{l}\text { Emotional } \\
\text { Responses of Urban } \\
\text { Walkers to Urban } \\
\text { Spaces }\end{array}$ & $\begin{array}{l}\text { their heart rate and blood pressure. } 2 \text {. } \\
\text { GPS and the data are clustered via } \\
\text { spatial statistics and GIS. 3. The data } \\
\text { are analyzed and a 3D map is produced } \\
\text { through GWR and Isovist. }\end{array}$ & & & \\
\hline 25 & 2016 & $\begin{array}{l}\text { Emotions and the } \\
\text { Urban Lighting } \\
\text { Environment: A } \\
\text { Cross-Cultural } \\
\text { Comparison }\end{array}$ & $\begin{array}{l}\text { 1. Selection of the research population } \\
\text { of students affiliated with } 3 \text { different } \\
\text { universities } 2 \text {. Use of laboratory } \\
\text { method and pictorial questionnaire } \\
\text { (each slide taking } 15 \text { minutes) and a } \\
\text { list of pre-specified feelings } 3 \text {. Data } \\
\text { analysis }\end{array}$ & $\begin{array}{l}\text { Experimental } \\
\text { (recreated } \\
\text { environmental } \\
\text { states)-correlation } \\
\text { al }\end{array}$ & $\begin{array}{l}\text { Mexico, Spain, } \\
\text { France }\end{array}$ & $\begin{array}{l}\text { (Calvillo Cortés } \\
\text { and Falcón } \\
\text { Morales 2016) }\end{array}$ \\
\hline 26 & 2016 & $\begin{array}{l}\text { Planning for Happy } \\
\text { Neighborhoods }\end{array}$ & $\begin{array}{l}\text { 1. Use of content analysis method and } \\
\text { document analysis of previous } \\
\text { research } 2 \text {. Definition of dimensions } \\
\text { and happiness } 3 \text {. Recognition of three } \\
\text { features of the created environment in } \\
\text { the vicinity directly related to } \\
\text { residents' happiness through } \\
\text { neighbors' participation }\end{array}$ & descriptive & - & $\begin{array}{l}\text { (Pfeiffer and } \\
\text { Cloutier 2016) }\end{array}$ \\
\hline 27 & 2016 & $\begin{array}{l}\text { Assessing Essential } \\
\text { Qualities of Urban } \\
\text { Space with } \\
\text { Emotional and } \\
\text { Visual Data Based } \\
\text { on GIS Technique }\end{array}$ & $\begin{array}{l}\text { 1. Mixed-use of field experiment, } \\
\text { qualitative and quantitative analytical } \\
\text { methods } 2 \text {. Collecting emotional data } \\
\text { through smart sensors and GPS } 3 \text {. } \\
\text { Spatial clustering to locate sampling } 4 \text {. } \\
\text { Development of Isovists to extract } \\
\text { textures 5. Use of logistic regression } \\
\text { analysis and probabilities affecting } \\
\text { public feelings }\end{array}$ & $\begin{array}{l}\text { Field } \\
\text { experiment-descri } \\
\text { ptive }\end{array}$ & $\begin{array}{l}\text { Zurich, } \\
\text { Switzerland }\end{array}$ & (Li et al. 2016) \\
\hline 28 & 2016 & $\begin{array}{l}\text { Mapping } \\
\text { Space-Related } \\
\text { Emotions out of } \\
\text { User-Generated } \\
\text { Photo Metadata } \\
\text { Considering } \\
\text { Grammatical Issues }\end{array}$ & $\begin{array}{l}\text { 1. Analysis of the content produced by } \\
\text { social network users } 2 \text {. Extraction of } \\
\text { positive and negative feelings tagged } \\
\text { on the photos of places } 3 \text {. Setting } \\
\text { places on maps } 4 \text {. use of a range of } \\
\text { color according to the positive or } \\
\text { negative feelings expressed in each } \\
\text { place }\end{array}$ & Descriptive & $\begin{array}{l}\text { Dresden, } \\
\text { Germany }\end{array}$ & $\begin{array}{l}\text { (Hauthal and } \\
\text { Burghardt 2016) }\end{array}$ \\
\hline 29 & 2017 & $\begin{array}{l}\text { The World } \\
\text { Happiness } 2017 \\
\text { Report }\end{array}$ & $\begin{array}{l}\text { In this report, about } 3000 \text { people per } \\
\text { country (about } 155 \text { countries) were } \\
\text { questioned on a measurement scale } \\
\text { and their responses were statistically } \\
\text { analyzed and presented schematically. }\end{array}$ & Correlational & 155 countries & $\begin{array}{l}\text { (Helliwell, } \\
\text { Huang, and } \\
\text { Wang 2017) }\end{array}$ \\
\hline 30 & 2017 & Mapping Emotion & $\begin{array}{l}\text { 1. Paper-based and online data } \\
\text { collection } 2 \text {. Visual data analysis and } \\
\text { interpretation (distribution of insecure } \\
\text { scary places overall, their distribution } \\
\text { day and night, their distribution in } \\
\text { terms of gender) by GIS } 3 \text {. Analysis of } \\
\text { the relevant factors to different } \\
\text { correlation methods } 4 \text {. development of } \\
\text { maps as a result of correlational factors }\end{array}$ & $\begin{array}{l}\text { Field } \\
\text { research-correlatio } \\
\text { nal }\end{array}$ & $\begin{array}{l}\text { Olomouc, } \\
\text { Czech Republic }\end{array}$ & $\begin{array}{l}\text { (Pánek, Pászto, } \\
\text { and Marek } \\
\text { 2017) }\end{array}$ \\
\hline
\end{tabular}

\section{RESEARCH METHODOLOGY}

The present research, which aimed to propose an operational model for the measurement of feelings, based on research methods and tools followed a content analysis method inductively and comparatively. Thus, initially, the related literature was reviewed as a 
document analysis of the research procedures and data collection methods used to delve into environmental psychology and urban studies related to emotions and feelings. This body of research, generally, included investigations of the methods used to collect data related to environmental psychology, feelings, and emotions. The content analysis yielded Figures 1 and 2. To this aim, from among the related literature, a sample of 30 projects conducted between 1998 and 2017 was selected. Then these projects were analyzed and compared in terms of the research methodology, instrumentation and data collection and analysis methods and the result were presented in Figures 1 and 2. Then, these studies were categorized in terms of the main research methods used in environmental psychology (presented in Table 2). Because of the content analysis of the sample, an operational model was proposed for the measurement of emotions and feelings along with five main steps in urban space. Figure 3 represents the research methodology.

\section{Fig. 3: Research Method Proses}

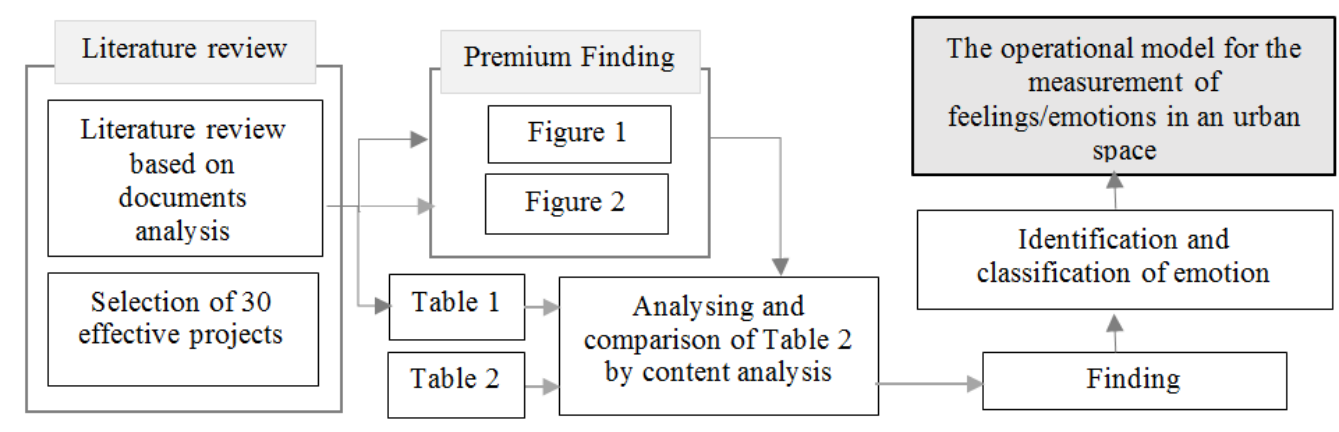

\section{FINDINGS AND DISCUSSION}

The analysis on the measurement of feeling and emotions and the methods used in research revealed that; today, the existing measurement and data collection methods in the realm of environmental psychology do not suffice on their own. Development of the latest technology, new maps of location-based urban feelings has contributed greatly to experts' planning of spatial design. Analog methods such as sketches and paper-based, descriptive plans have been mixed with digital technology such as smart devices and mobile phones as well as computer-based software and smart programs.

In all the body of literature reviewed along with their methodologies, there was one procedure to measure feelings which could be categorized according to the purpose of the target research and in the majority of the literature reviewed, feelings were manifested through maps or as a layer added to navigation maps which showed the extent of emotions depending on the purpose of research.

Moreover, in the majority of the projects reviewed, not a single method sufficed to measure feelings in urban areas. Investigations showed that to achieve the purpose of the research and measure the target feelings, mixed methods were used such as mixed field and correlational research (e.g. "An investigation of the evaluative mental map of cities", Sensing the city, Testing Testing, Emocycling, Mapping Feeling, EmoBeL along with the spatial analysis of how passerby's emotional responses related to urban spaces) or the mixed correlational and descriptive methods (as in WiMo, EmoMap, Aleph of Emotion projects, manifestation of emotional clues in cities, emotional compass). 
Rezaee E. D., Kalantari F.: Proposal of an Operational Model to Measure Feelings and Emotions in Urban Space

Furthermore, in the majority of the literature reviewed, the self-rating method was the dominant data collection method. Such mixed data collection methods as observation-self-rating were also used to measure feelings towards space.

Also, among the data collection procedures, questionnaire completion through a device or an application as well as the record of physiological signals (use of a smart bracelet to check skin temperature and wetness and the heart rate) were used most frequently. Instances are the following projects: Bio Mapping, VEMap, EmoMap, Sensing the city, Testing Testing, Emocycling, EmoBeL, SensorMapRT, etc.

In summarize, among the key obstacles and challenges of measuring feelings in a space that need to be considered before and during the target attempts are scalability, maintenance of privacy, no tagging of information, mismatch of feelings and place, disintegrated data and the limited battery life of the measurement device.

Moreover, the analysis of the 30 projects revealed that the concept of urban feelings and emotions can be a new human-oriented approach that attempts to collect data through individuals with the help of sensor technology to unravel spatial feelings. It can act as a new layer of information and contribute greatly to the planning work of an expert. Thus, for the sake of methodology and measurement of feelings and emotions in an urban space, it is necessary to go through a certain procedure and know its steps. According to the above-mentioned issues which show point to the steps involved in the measurement procedure of feelings, Figure 4 represents the operational model of measuring emotions and feelings in an urban space.

According to Figure 4, the feeling/emotion measurement process can be divided into 5 main steps:

1. Recognition of measurable factors involved in feelings/emotions: This step requires that we know the purpose of our research and the variable mainly related to feelings that we want to measure. Among such variables are the natural and manufactured environment, physical structure, memories, perception, interaction with others and the application of the environment.

2. Research methods of measuring feelings: This step involves the selection of the research method before the conduction of research according to the target factor involved. Such research methods used to track feelings are field experiment, field research, and correlation, a mixture of two or more methods just mentioned.

3. Data collection and evaluation: In this step, people's emotional data are collected through different tools such as smart mobile phones, sensors that can be worn (e.g. bracelets, etc.), digital camera, personal accounts (self-ratings), physiological signals, facial or voice effects, spatial data, and social networks.

4. Analysis: In this step, data analysis is done in the light of visual cognition and perception of the previous step.

5. The manifestation of feelings: This step involves the presentation of maps and applications to contribute to urban planning and design in the light of the urban feelings expressed by citizens. Moreover, updating these emotional data through software and providing access for all is done in this step to improve the quality of the urban environment. The output would be the feelings measured in space. 
Fig. 4: The operational model for the measurement of feelings/emotions in an urban space

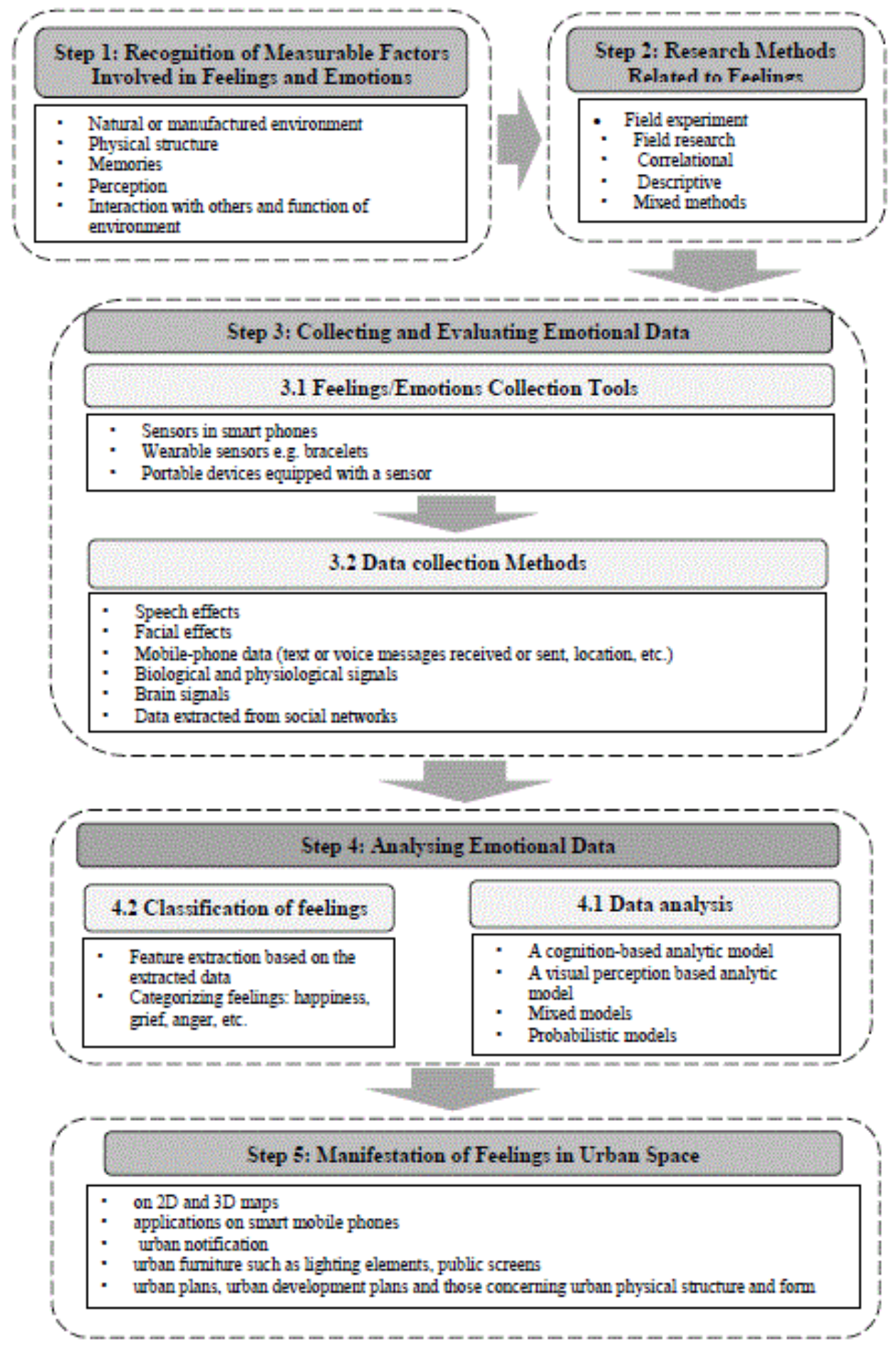


Rezaee E. D., Kalantari F.: Proposal of an Operational Model to Measure Feelings and Emotions in Urban Space

\section{CONCLUSION}

Today, human beings are faced with quite many environmental factors affecting psychological health. Recognition of these factors and measurement instruments are of great concern. As the focus of environmental psychology is on how behavior and emotion are influenced by the physical environment, the theoretical basis of the present research is in social psychology and sociology. It thus does not have an independent research methodology and instrumentation. The present research aims to introduce new methods and instruments to measure emotions in urban space. Moreover, unfortunately, due to the unsystematic and unreliable construction of metropolises, destruction of natural spaces and the consequent visual pollution, boring traffic jam, populated areas, noise, and air pollution, living in metropolises seems to become intolerable. Undesirable conditions of living in populated cities have given rise to such diseases as depression, anxiety, physical and psychological disorders.

What can raise the success of urban studies especially urban planning more than ever before is the recognition of how people behave, perceive and feel? Knowing public feelings, emotions wants, and ideas do not necessarily mean the provision of solutions, desirable ideas and want (Eshuis \& Edwards, 2013). In fact, the primary purpose of the present research is the introduction of a process to measure feelings. The present authors believe that innovation in the concept of urban feelings depends on the super-cognitive nature of urban studies and the super-methods used. It enjoys a mixture of different research methods plus certain specific methods from among different disciplines (psychology, sociology, urban studies, computer sciences, etc.) to solve urban problems. Thus, this new information layer which provides for a better perception of urban structure helps to design more desirable urban spaces and those of higher quality by urban designers and planners.

In fact, the main innovation of the urban emotions concept lies in the metacognitive and methodological nature. Therefore, this new information contributes to a better understanding of the urban structure and a more appealing urban design. Overall, the high level of mental problems threatening citizens such as depression, stress, anxiety and so on in Today's world as well as attempts to raise the quality of urban environments accompanied by more and more social activities and interactions have drawn further attention to personal feelings especially positive emotions such as happiness in recent years. An investigation of effective environmental factors helps to increase the level of these positive feelings and decrease negative effects. As perceived by experts, a good urban space can lead to public joy and satisfaction with living conditions. The more appropriate one's place of living, the happier life one can live. This positive feeling results from a myriad of factors. In fact, living in a happy city would create emotional dependencies on the neighborhood and people living nearby.

\section{REFRENCES}

Bell, P.A, Greene, T.C, Fisher, J.D, Baum, A., (2001). Environmental Psychology. Fifth. Ward worth group, Thomas Learning, USA.

Bergner, B.S. et al. (2011). Emotional Barrier-GIS-A New Approach to Integrate Barrier-Free Planning in Urban Planning Processes. In REAL CORP 2011: CHANGE FOR STABILITY: Lifecycles of Cities and Regions, , 1-11. Retrieved September 15, 2011, from https://pdfs.semanticscholar.org/b519/ 3689d19f70566caea59c47d0c9176ea8049c.pdf.

Bergner, B. S., Exner, J.-P, Zeile, P. Rumberg, M., (2012). Sensing the City - How to 
Identify Recreational Benefits of Urban Green Areas with the Help of Sensor Technology. In REAL CORP 2012: RE-MIXING THE CITY - Towards Sustainability and Resilience?, 73746. Retrieved April 5, 2012, from https://programm.corp.at/cdrom2012/papers2012/ CORP2012_60.pdf.

Berleant, A., (2018). Aesthetics and Environment: Variations on a Theme. 1st Editio. London, UK: Routledge.

De Botton, A., (2008). The Architecture of Happiness. Vintage.

Calvillo C., Berenice, A., Falcón Morales, L.E., (2016). Emotions and the Urban Lighting Environment. SAGE Open 6(1). DOI: http://journals.sagepub.com/doi/10.1177/215824401 6629708.

Cook, E.M., Hall, Sh.J., Larson, K.L., (2012). Residential Landscapes as Social-Ecological Systems: A Synthesis of Multi-Scalar Interactions between People and Their Home Environment. Urban Ecosystems 15(1): 19-52. DOI: http://link.springer.com/ 10.1007/s11252 -011-0197-0.

Edwards, M., (1974). Comparison of Some Expectations of a Sample of Housing Architects with Known Data. Psychology and the built environment: 38-47.

Eshuis, J., Edwards, A., (2013). Branding the City: The Democratic Legitimacy of a New Mode of Governance. Urban Studies 50(5): 1066-82. DOI: http://journals.sagepub.com /doi/10.1177/0042098012459581.

Exner, J-P. et al. (2015). SensorMapRT-a System for Real-Time Acquisition, Visualization and Analysis of Mobile Sensor Data in an Urban Context. In REAL CORP 2015. PLAN TOGETHER-RIGHT NOW-OVERALL. From Vision to Reality for Vibrant Cities and Regions. Proceedings of 20th International Conference on Urban Planning, Regional Development and Information Society (pp. 855-60), CORP-Competence Center of Urban and Regional Planning.

Gartner, G., (2012). Emotional Response to Space as an Additional Concept in Cartography. In ISPRS - International Archives of the Photogrammetry, Remote Sensing and Spatial Information Sciences, Melbourne, Australia, 473-76. Retrieved December 1, 2002, from http://www.int-arch-photogramm-remote-sens-spatial-inf-sci.net/XXXIX-B4/ 473/2012/.

Gifford, R., (2016). Research Methods for Environmental Psychology. West sussexes: John Wiley \& Sons.

Graumann, C.F., (2002). The Phenomenological Approach to People-Environment Studies. Handbook of environmental psychology: 95-113.

Groß, D., Zeile, P., (2016). EmoCyclingConcept-Potenziale Der Emotionalen Stadtkartierung. AGIT - Journal für Angewandte Geoinformatik 2: 273-78. DOI: https://pdfs.semanticscholar.org/46e7/cef4948f73e790706ddcb8a69975154e72e6.pdf.

Handgraaf, M., Griffioen, A., Bolderdijk, J.W., Thøgersen, J. (2017). Economic Psychology and Pro-Environmental Behaviour. In Economic Psychology (pp. 435-450), Chichester, UK: John Wiley \& Sons, Ltd.DOI: http://doi.wiley.com/10.1002/9781118926352.ch27.

Hauthal, E., Burghardt, D., (2016). Mapping Space-Related Emotions out of User-Generated Photo Metadata Considering Grammatical Issues. The Cartographic Journal 53(1): 78-90. DOI: http://www.tandfonline.com/doi/full/10.1179/1743277414Y.0000000094.

Helliwell, J.F, Huang, H., Wang, S., (2017). World Happiness Report 2017 The Social Foundations of World Happiness.

Henshaw, V. et al. (2012). Emotion in Motion: A Methodology for Investigating Emotional 
Rezaee E. D., Kalantari F.: Proposal of an Operational Model to Measure Feelings and Emotions in Urban Space

Response to the Streets and Urban Spaces in Hanley, Stoke-on-Trent. In IAPS 2012 Conference, Human Experience in the Natural and Built Environment, Glasgow.

Henshaw, V., Mould, O.T., (2013). Sensing Designed Space: An Exploratory Methodology for Investigating Human Response to Sensory Environments. J. of Design Research 11(1): 57-71. DOI: http://www.inderscience.com/link.php?id=54066.

Hijazi, I.H. et al. (2016). Geostatistical Analysis for the Study of Relationships between the Emotional Responses of Urban Walkers to Urban Spaces. International Journal of E-Planning Research 5(1): 1-19. DOI: https://e-pub.uni-weimar.de/opus4/frontdoor/deliver /index/docId/2602/file/Hijazi-pdfa.pdf.

Holbrook, M.B., Hirschman, E.C., (1982). The Experiential Aspects of Consumption: Consumer Fantasies, Feelings, and Fun. Journal of consumer research 9(2): 132-40. DOI: https://academic.oup.com/jcr/article-abstract/9/2/132/1813212.

Iaconesi, S., Persico, O., (2013). An Emotional Compass: Harvesting Geo-Located Emotional States from User Generated Content on Social Networks and Using Them to Create a Novel Experience of Cities. In CEUR Workshop Proceedings (pp. 181-199).

Iaconesi, S., Persico, O., (2014). Vizualizace emocionálních památek ve městech. V roce 2014 18. mezinárodní konference o vizualizaci informací, IEEE, 408-13. http://ieeexplore.ieee.org/document/7154913/.

Jiao, L., (2015). Urban Land Density Function: A New Method to Characterize Urban Expansion. Landscape and Urban Planning 139: 26-39. DOI: http://linkinghub. elsevier.com/retrieve/pii/S0169204615000481.

Kalantari, F., Mohd Tahir, O., Akbari Joni, R., Aminuldin, N.A., (2018). The Importance of the Public Acceptance Theory in Determing the Succes of the Vertical Farming Projects. MANAGEMENT RESEARCH AND PRACTICE 10(1): 5-16.

Kalantari, F., Mohd Tahir, O., Golkar, N., Ismail, N.A., (2015). Socio-Cultural Development of Tajan Riverfront, Sari, Iran. Advances in Environmental Biology 9(27): 386-92.

Klettner, S., Gartner, G., (2012). Modelling Affective Responses to Space. In REAL CORP 2012. Re-Mixing the City. Towards Sustainability and Resilience? (pp. 485-491). Retrieved September 5, 2012, from https://programm.corp.at/cdrom2012/papers2012/ CORP2012_213.pdf.

Klettner, S., Huang, H., Schmidt, M., (2011). EmoMap - Considering Emotional Responses to Space for Enhancing LBS. In 8th International Symposium on Location-Based Services, Vienna (pp. 300-303).

Li, X. et al. (2016). Assessing Essential Qualities of Urban Space with Emotional and Visual Data Based on GIS Technique. ISPRS International Journal of Geo-Information 5(11): 1-18. DOI: http://www.mdpi.com/2220-9964/5/11/218.

Lindner, Ch., (2009). Globalization, Violence and the Visual Culture of Cities Globalization, Violence and the Visual Culture of Cities. Routledge. Retrieved December 15, 2009, from https://www.taylorfrancis.com/books/9780203885079.

Lundy, L., Wade, R., (2011). Integrating Sciences to Sustain Urban Ecosystem Services. Progress in Physical Geography 35(5): 653-69. DOI: http://journals.sagepub.com/ doi/10.1177/0309133311422464.

Mancini, C. et al. (2009). From Spaces to Places. In Proceedings of the 11th International Conference on Ubiquitous Computing - Ubicomp '09, New York, New York, USA: ACM Press, 1. Retrieved December 8, 2009, from http://portal.acm.org/citation.cfm? 
doid=1620545.1620547.

Matei, S., Ball-Rokeach, S. J., Linchuan Qiu, J., (2001). Fear and Misperception of Los Angeles Urban Space,A Spatial-Statistical Study of Communication-Shaped Mental Maps. Communication Research 28(4): 429-63. DOI: http://journals.sagepub.com/ doi/10.1177/009365001028004004.

Mazumdar, S., Learnihan, V., Cochrane, T., Davey, R., (2018). The Built Environment and Social Capital: A Systematic Review. Environment and Behavior 50(2): 119-58. DOI: http://journals.sagepub.com/doi/10.1177/0013916516687343.

McAndrew, F. T. (1993). Environmental Psychology. Thomson Brooks/Cole Publishing Co. Mody, R.N, Willis, K.S, Kerstein, R., (2009). WiMo: Location-Based Emotion Tagging. In Proceedings of the 8th International Conference on Mobile and Ubiquitous Multimedia, ACM, 14.

Nardi, P.M., (2018). Doing Survey Research: A Guide to Quantitative Methods. Routledge. Nasar, J.L., (1990). "The Evaluative Image of the City." Journal of the American Planning Association 56(1): 41-53. DOI: http://www.tandfonline.com/doi/abs/10.1080/ 01944369008975742.

Nochian, A., Mohd Tahir, O., Maulan, S., Reza Mikaeili, A., (2016). A Review of Systematic Approach for Sustainable Redevelopment of A Closed Landfill Site. Jurnal Teknologi 78(5): 299-307. DOI: https://jurnalteknologi.utm.my/index.php/jurnalteknologi/article/view/8318.

Nochian, A., Mohd Tahir, O., Maulan, S., Rakhshandehroo, M., (2015). A Comprehensive Public Open Space Categorization Using Classification System for Sustainable Development of Public Open Spaces. ALAM CIPTA, International Journal on Sustainable Tropical Design Research \& Practice 8(spec. 1): 29-40.

Nold, Ch., (2009). under a Creative Commons, Attribution, NonCommercial, ShareAlike Licence Emotional Cartography: Technologies of the Self.

Nold, Ch, Jensen, O.B., Harder, H., (2008). Mapping the City: Reflections on Urban Mapping Methodologies from GPS to Community Dialogue. Department of Architecture and Design, Aalborg University, Denmark. Retrieved November 10, 2008, from http://www.forskningsdatabasen.dk/en/catalog/2389384861.

Pánek, J., Pászto, V., Marek, L., (2017). Mapping Emotions: Spatial Distribution of Safety Perception in the City of Olomouc. In Lecture Notes in Geoinformation and Cartography (pp. 211-24). http://link.springer.com/10.1007/978-3-319-45123-7_16.

Pfeiffer, D., Cloutier, S., (2016). Planning for Happy Neighborhoods. Journal of the American Planning Association 82(3): 267-79. DOI: http://www.tandfonline.com/doi/ full/10.1080/01944363.2016.1166347.

Podsakoff, P.M, MacKenzie, S.B., Lee, J-Y., Podsakoff, N.P., (2003). Common Method Biases in Behavioral Research: A Critical Review of the Literature and Recommended Remedies. Journal of applied psychology 88(5): 879.

Quercia, D., Schifanella, R., Aiello, L.M., (2014). The Shortest Path to Happiness. In Proceedings of the 25th ACM Conference on Hypertext and Social Media - HT '14 (pp. 116125). New York, New York, USA: ACM Press. Retrieved September 18, 2014, from http://arxiv.org/abs/1407.1031.

Raslan, R., Al-hagla, K., Bakr, A., (2014). Integration of Emotional Behavioural Layer 'EmoBeL' in City Planning. Real Corp 2014-PLAN IT SMART! Clever Solutions for Smart Cities. Proceedings of 19th International Conference on Urban Planning, Regional 
Rezaee E. D., Kalantari F.: Proposal of an Operational Model to Measure Feelings and Emotions in Urban Space

Development and Information Society 8(May) (pp. 309-317). Retrieved Juny 15, 2014, from http://www.corp.at.

Rezazadeh, R.H.S. (1999). Shaping the Streetscape: Developing Principles for Design of Street Facades (the Case of Tehran), Iran. (Unpublished Ph.D Thesis), University of Sheffield, School of Architectural Studies.

Russell, J.A., (2003). Core Affect and the Psychological Construction of Emotion. Psychological review 110(1): 145. Retrieved Juny 20, 2003, from http://psycnet.apa.org/ record/2002-08416-007.

Scherer, K.R., (2005). What Are Emotions? And How Can They Be Measured? Social science information 44(4): 695-729. DOI: http://journals.sagepub.com/doi/abs/ $10.1177 / 0539018405058216$.

Tress, W. et al. (2018). Interpretation and Evolution of Open-Circuit Voltage, Recombination, Ideality Factor and Subgap Defect States during Reversible Light-Soaking and Irreversible Degradation of Perovskite Solar Cells. Energy \& Environmental Science 11(1): 151-65. DOI: http://xlink.rsc.org/?DOI=C7EE02415K.

Ujang, N., Kozlowski, M., Maulan, S., (2018). Linking Place Attachment and Social Interaction: Towards Meaningful Public Places. Journal of Place Management and Development 11(1): 115-29. DOI: http://www.emeraldinsight.com/doi/ 10.1108/JPMD-01-2017-0012.

Vigneshwara, M., (2014). Aleph of Emotions Comparing Global Online Emotions. In Proceedings of the 8th International Conference on Tangible, Embedded and Embodied Interaction, ACM, (pp. 330-331).

Vinet, L., Zhedanov, A. (2010). A 'Missing' Family of Classical Orthogonal Polynomials. Urban Ecology: 143-58. DOI: http://link.springer.com/10.1007/978-0-387-73412-5_9.

Weinreb, A.R., Rofè, Y. (2013). Mapping Feeling: An Approach to the Study of Emotional Response to Built Environment and Landscape ENVIRONMENT AND LANDSCAPE. Journal of Architectural and Planning Research (July): 127-45.

Wertz, F.J., (2005). Phenomenological Research Methods for Counseling Psychology. Journal of Counseling Psychology 52(2): 167-77. DOI: http://doi.apa.org/ getdoi.cfm?doi=10.1037/0022-0167.52.2.167.

Zeile, P., Höffken, S., Papastefanou, G., (2009). Reviewed Paper Mapping People? - The Measurement of Physiological Data in City Areas and the Potential Benefit for Urban Planning Peter Zeile, Stefan Höffken, Georgios Papastefanou. Proceedings of RealCORP 2009 6(April): 341-52.

Zhu, H., (2009). VEMap: A Visualization Tool for Evaluating Emotional Responses in Virtual Environments. (Master's Thesis).University of Waterloo, Ontario, Canada. 